\title{
DEVELOPMENT AND CHANGE
}

Published on behalf of the Institute of Social Studies, The Hague

Edited by Martin Doombos, Astwwani Saith and Ben White

Development and Change with more than 20 years of impressive intellectual performance, continues to reaffirm and renew its pivotal position in development studies as the main non-sectarian, multidisciplinary venue for informed reflection and debate on key themes and trends in the analysis of development. Development and Change is critically reconnoitering the shifting terrain of

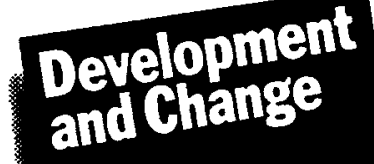
development discourse, aided by the more than 400 authors that have appeared in its pages and the active participation of an ever-widening and diverse group of readers, referees, reviewers and Advisory Editors from every discipline concerned with development. Development and Change features an extensive book review section, periodic special theme issues and important theoretical debates and welcomes notes and comments on its content.

Published quarterly in January, April, July and October.

\section{Try out a subscription at the introductory $20 \%$ discount rate}

\section{$20 \%$ Discount Onder Form}

Send this order form to:

\section{Sage Publications}

6 Bontil Street, London EC2A 4PU, UK Tet: $071-3740645$

US Onders to:

Sege Publlations, PO Bax 5096, Newbury Part, CA 91359, USA

Q Yesl I want to subscribe to Development and Change at a $20 \%$ Discount

0 individeal Rate at E27(234') S44(555")

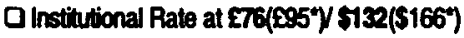

Usual 1993 rate

Name

Address

\section{Three ways to pay!}

DChequel._. I enclose a cheque (made payable to Sage Publications)

口Girol... I have today paid by International Giro to Ac No 5480353

QCredit Cardl... Please charge my credit card

- Mastercard DAccess Q Visa

- Barclaycard D American Express

o Diners Chb a Eurocard

Card Number

Expiry Date

Signature

Date 


\section{Re-Entry Grants for African Scholars Pursuing Education Research}

This grants program is designed to assist in the professional re-establishment of talented African scholars who are returning from doctoral or post-doctoral studies abroad and wish to pursue research related to the revitalization and development of education in sub-Saharan Africa. All proposed projects must include an explicit and substantial focus on female school participation as part of the set of issues to be examined.

The proposed budget, not to exceed $\$ 25,000$, may request funding for items such as a microcomputer and software, books, office supplies, living expenses, personnel assistance and local transportation. The budget may also include subsistence for one research team member of any nationality and a stipend to cover up to six months' transition costs for the principal researcher.

Applicants may submit research proposals prior to or within one year of returning to their Africa-based institutions. The proposal must be endorsed by the African institution where the applicant will be a full-time staff member. Also required are: two letters of recommendation from academic supervisors at the institution where the candidate carried out doctoral or post-doctoral study; doctoral transcripts; and resumes for the applicant and any professional research team member for whom funds are sought.

There are no deadlines for submission of proposals. For a full description of the program, write to:

Scholars on Education Re-Entry Program or

The Rockefeller Foundation

1133 Avenue of the Americas

New York, New York 10036 USA

Scholars on Education Re-Entry Program

The Rockefeller Foundation

P.O. Box 47543

Nairobi, Kenya 


\section{THE JOURNAL OF MODERN AFRICAN STUDIES}

The Joumal offers a quarterly survey of politics, economics, and related topics in contemporary Africa.

The main emphasis is upon the peoples and policies, the problems and progress of this dynamic and disparate continent; upon the many societies that are evolving rather than the essential characteristics of the old; upon the present, not on the more distant past. The best current work is presented from specialists in different academic disciplines, whose contributions can illuminate and cross-fertilise one another.

The foumal seeks to promote a deeper understanding of what is happening in Africa today. It is intended for both the political scientist and the practical politician, the administrator and the advocate, the economist and the educator, the banker and the business man, the diplomat and the technocrat, the civil servant and the nationalist leader. All have something to contribute to these pages and, it is hoped, much to learn from them.

Editorial policy avoids commitment to any political viewpoint or ideology, whether imperialism, pan-Africanism, capitalism, socialism, or nationalism. Such concepts, however, have relevance to the modern African situation, and merit serious discussion, often from several different points of view, in order that controversial issues may be fairly examined.

C Cambridge University Press 1993

Contributors of accepted articles will be asked to assign their copyright, on certain conditions, to Cambridge University Press, to help protect their material, particularly in the USA.

\section{Copying}

This journal is registered with the Copyright Clearance Center, 27 Congress St., Salem, Mass. or970. Organisations in the USA who are also registered with C.C.C. may therefore copy material (beyond the limits permitted by sections 107 and 108 of US copyright law) subject to payment to C.C.C. of the per copy fee of $\$ 5.00$. Code $0022-278 x / 93 / \$ 5.00+.00$. This consent does not extend to multiple copying for promotional or commercial purposes. ISI Tear Sheet Service, 350I Market Street, Philadelphia, Pennsylvania 19104, USA, is authorised to supply single copies of separate articles for private use only. Organizations authorized by the Copyright Licensing Agency may also copy material subject to the usual conditions. For all other use, permission should be sought from Cambridge or the American Branch of Cambridge University Press.

\section{CAMBRIDGE UNIVERSITY PRESS}

The Pitt Building, Trumpington Street, Cambridge CB2 IRP

40 West $20 t h$ Street, New York, NY $10011^{-4} 421$, USA

ro Stamford Road, Oakleigh, Melbourne 3166 , Australia 


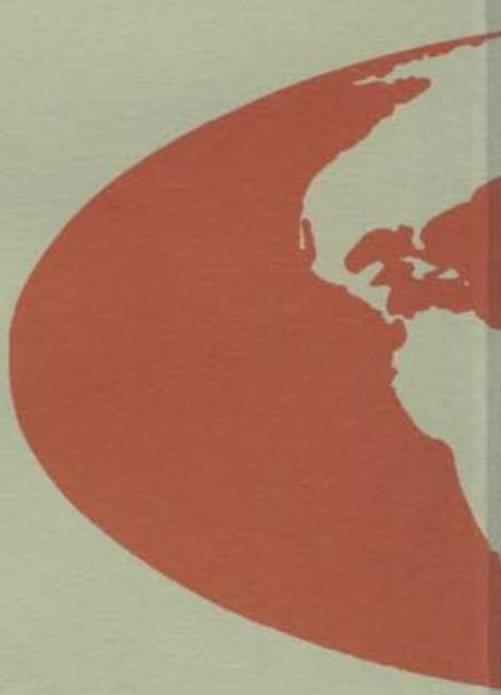

\section{CAMBRIDGE} UNIVERSITY PRESS

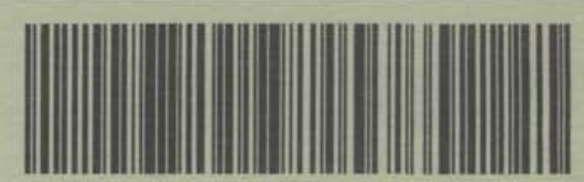

0022-278X(199307)31:3;1-3 